\title{
PEMBERDAYAAN MASYARAKAT TRANSMIGRASI DI DESA GUNUNG PUTIH DAN DESA TANJUNG BUKA MELALUI REVOLUSI MENTAL DALAM MEWUJUDKAN INDONESIA BERSIH DAN INDONESIA MANDIRI
}

\author{
Community Empowerment Of Transmigration In The Village Of White Mountain And The Village \\ Of Tanjung Open Through A Mental Revolution In Realizing Clean And Independent Indonesian
}

\author{
Arif Rohman ${ }^{1}$, Aditia Syaprillah ${ }^{2}$ \\ ${ }^{1,2}$ Fakultas Hukum, Universitas Borneo, Jl. Amal Lama No. 01 \\ ${ }^{1}$ Penulis Korespodensi : arifrohman.ubt@yahoo.com
}

\begin{abstract}
ABSTRAK
Pemberdayaan masyarakat merupakan treding topik setiap kegiatan pengabdian kepada masyarakat, hal ini dibuktikan dengan sasaran utama oleh perguruan tinggi dalam melaksanakan tugas dan fungsinya sebagai lembaga pendidikan tinggi yang kompeten sehingga dengan keberadaan perguruan tinggi di setiap daerah membawa dampak positif bagi masyarakat. Pemberdayaan yang dimaksudkan disini adalah berkaitan dengan nawacita presiden yakni melalui revolusi mental khususnya membentuk pola pikir masyarakat kesadaran atas kebersihan dan kemandirian dengan memanfaatkan potensi yang ada di desanya masing-masing. Selama pelasakaan kegiatan ini, rata-rata masyarakat tidak menyadari akan potensi yang dapat dimanfaatkan untuk kemandirian desanya yang dapat menumbuhkembangkan pemasukan bagi desanya. Dari hasil pelaksanaan kegiatan terlihat bahwa kurangnya kepedulian masyarakat baik yang ada di desa tanjung buka maupun desa gunung putih akan kebersihan, terlihat bahwa masih banyaknya sampah yang berserakan di sekitar jalan dikarenakan tidak tersedianya tempat sampah. Kemudian sampah-sampah yang ada juga belum dimanfaatkan secara maksimal. Serta pemanfaatan potensi di desa-desa tersebut juga tidak dimanfaatkan, padahal selian tanah yang subur potensi aliran sungai dan gunung yang belum dikelola dengan baik.
\end{abstract}

Kata Kunci : Pemberdayaan, Transmigrasi, Revolusi Mental dan Desa

\begin{abstract}
Community empowerment is the topic of every activity treding devotion to society, this is proven by the main target by the College in carrying out the tasks and functions as a competent institution of higher education so that with the existence of colleges in each region brought a positive impact for the community. Empowerment is meant here is related to the nawacita the President i.e. through a mental revolution in particular form the mindset of the public awareness of hygiene and self-reliance by making use of the existing potential in his village. During the pelasakaan of this activity, the average Community is not aware of the potential that can be harnessed to his independence which can menumbuhkembangkan income for his village. From the results of the implementation of the activities of the community's concern that the lack of visible either in the village or mountain village headlands open white will still be seen that cleanliness, the number of garbage scattered around the street due to the unavailability of the trash. Then garbage-garbage that there's also yet underutilized. As well as exploiting the potential in these villages also not utilized, whereas selian fertile potential of flow of rivers and mountains that have not been managed properly.
\end{abstract}

Keywords: Empowerment, Transmigration, Mental Revolution and Village

\section{PENDAHULUAN}

Kabupetan Bulungan merupakan salah satu kabupaten yang memiliki daya tarik tersendiri bagi masyarakat Indonesia. Salah satu daya tersebut adalah upaya untuk mengembangkan kabupaten bulungan melalui program pemerintah berupa Transmigrasi. Daerah transmigrasi yang ada di wilayah Kabupaten Bulungan tersebar di beberapa kecamatan, seperti Kecamatan Tanjung Palas, Kecamatan Tanjung Palas Timur, Kecamatan Tanjung Palas Barat, Tanjung Palas Tengah dan Kecamatan Tanjung Palas Utara. Sebagai masyarakat yang berada pada daerah transmigrasi untuk mengembangkan diri tidaklah mudah, banyak 
dari mereka yang kembali ke daerah asal (pulau jawa) ada juga yang migrasi ke Ibukota Kabupaten karena untuk mempertahankan hidup dan mengembangkan diri melalui perdagangan.

Perlu diketahui bahwa potensi utama daerah transmigrasi yang diwacanakan oleh pemerintah adalah sektor pertanian. Tetapi banyak potensi daerah transmigrasi yang tidak hanya berpaku pada pertanian seperti yang ada di desa gunung putih tanjung palas yang mulai menggali potensinya berupa rumput gajah yang dijadikan sebagai pupuk organik.

Program Transmigras sudah ada sejak 42 tahun yang lalu di Kalimantan Utara atau sekitar tahun 1972. Dengan mendatangkan transmigran dari Pulau Jawa, program transmigrasi yang dilaksanakan di wilayah ini dinilai sangat berhasil. Hingga saat ini sudah ada 40 ribu warga yang dulunya bertransmigrasi di Kalimantan Utara. Bahkan kalau dihitung secara persentase jumlah penduduknya, hampir 10 persen merupakan warga transmigran.

Permasalahan yang dialami oleh masyarakat transmigrasi selama ini adalah kurangnya penggalian potensi yang ada di daerah transmigrasi. Konsep transmigrasi yang dipahami adalah pembangunan pertumbuhan ekonomi melalui sektor pertanian. Sehingga keadaan masyarakat transmigrasi yang ada adalah jauh dari harapan harena hanya bertumpu pada sektor pertanian yang kurang melirik potensi lain.

Sektor pertanian selama ini diharapkan mampu mendongkrak ekonomi yang ada di wilayah kabupaten bulungan. Sebetulnya melalui program revolusi mental atau pemahaman konsep masyarakat transmigrasi untuk dapat mewujudkan desa bersih dan desa mandiri. Diharapkan perubahan konsep tersebut, desa gunung putih/tanjung palas dan desa tanjung buka mampu mengembangkan masyarakatnya menuju desa bersih dan desa mandiri.

\section{METODE}

Metode pelaksanaan dari kegiatan pengabdian kepada masyarakat ini antara lain:

1. Persiapan

a. Persiapan yang dilakukan adalah pembagian materi dan konsep pemikran tentang desa bersih dan desa mandiri. Dengan adanya pembagian konsep, maka akan didapatkan distribusi kegiatan yang diinginkan dan diharapkan berjalan dengan baik. b. Merancang indikator yang dapat digunakan oleh tim pelaksana.

2. Pelaksaan

Selama pelaksanaan yang dilakukan adalah sosialisasi dan pembagian peralatan yang berkaitan dengan desa bersih dan desa mandiri.

3. Evaluasi

Evaluasi diperlukan sebagai sarana untuk mengetahui seberapa besar keberhasilan pelaksanaan kegiatan pengabdian kepada masyarakat.

\section{HASIL DAN PEMBAHASAN}

\section{a. Perkembangan Revolusi Mental dan Desa}

Kata "revolusi" berasal dari bahasa Inggris yang berarti: "putaran", "baling- an", "perkisaran", "perubahan", dan "pu- singan" (J.M. Echols \& Hassan Shadily, 2010). Dalam Kamus Besar Bahasa Indonesia (1992), kata revolusi diartikan sebagai (1) perubahan ketatanegaraan (pemerintahan atau keadaan sosial) yang dilakukan dengan kekerasan (seperti de- ngan perlawanan bersenjata); (2) perubahan yang cukup mendasar dalam suatu bidang; (3) peredaran bumi dan planet-planet lain dalam mengelilingi matahari.

Menurut Yudi Latif secara denotatif, revolusi berarti "kembali lagi" atau "berulang kembali"; ibarat musim yang berganti secara siklikal untuk kembali ke musim semula. Berdasarkan pengertian ini, maka dalam sains istilah revolusi mengimplikasikan suatu kete- tapan (konstanta) dalam perubahan; pengulangan secara terus-menerus yang menjadikan akhir sekaligus awal.

Istilah "revolusi" pada awalnya merupakan sebuah istilah dalam sains astronomi yang digunakan untuk meng- gambarkan siklus pergerakan (movement) benda-benda langit (Leahey, 1992). Pada tahun 1543, Nicholaus Copernicus mempublikasikan buku De Revolutionibus Orbium Coelestium, yang sering dinisbatkan sebagai penanda revolusi paradigmatik dalam sains yang mengubah keyakinan tentang pusat alam semesta dari geosentrisme (berpusat di bumi) menuju heliosentrisme (berpusat di matahari) perubahan mendasar dalam keyakinan ilmiah ini kemudian dikenal sebagai revolusi Copernican.

Pada 6 Desember 2016 lalu, Presiden Joko Widodo (Jokowi) menandatangani Instruksi Presiden Nomor 12 Tahun 2016 tentang Gerakan Nasional Revolusi Mental. Tujuan Inpres ini untuk memperbaiki dan membangun karakter bangsa 
dengan mengacu pada nilai-nilai integritas, etos kerja dan gotong royong untuk membangun budaya bangsa yang bermartabat, modern, maju, makmur dan sejahtera berdasarkan Pancasila. Dituangkannya program revolusi mental dalam perpres tersebut adalah sebagai acuan pemerintah dalam menjalankan program kegiatan untuk Indonesia yang lebih maju dan lebih baik.

Adapun 5 (lima) program Revolusi Mental dijelaskan sebagai berikut. Pertama, Program Gerakan Indonesia Melayani. Program ini difokuskan kepada peningkatan kapasitas sumber daya manusia aparatur sipil negara(ASN),peningkatan penegakan disiplin aparatur pemerintah dan penegak hukum,penyempurnaan standar pelayanan dan sistem pelayanan yang inovatif (e-government).

Kedua, Program Gerakan Indonesia Bersih. Program ini fokus padapeningkatan perilaku hidup bersih dan sehat lingkungan keluarga, satuan pendidikan, satuan kerja, dan komunitas, peningkatan sinergi penyediaan sarana dan prasarana yang menunjang perilaku hidup bersih dan sehat. Pengembangan sistem pengelolaan sampah yang holistik dan terintegrasi termasuk kali bersih, sarana dan prasarana pelayanan publik, deregulasi, pemberian kemudahan bagi perusahaan/swasta/lembaga yang melakukan pengelolaan sampah, mengutamakan peran serta masyarakat di dalam menunjang perilaku bersih dan sehat dan peningkatan penegakan hukum di bidang kebersihan dan kesehatan lingkungan.

Ketiga, Program Gerakan Indonesia Tertib. Program ini fokus pada peningkatan perilaku tertib penggunaan ruang publik, peningkatan perilaku tertib pengelolaan pengaduan, peningkatan perilaku tertib administrasi kependudukan, peningkatan perilaku tertib berlalu lintas, peningkatan perilaku antre, peningkatan sinergi penyediaan sarana dan prasarana penunjang perilaku,peningkatan penegakan hukum perilaku tertib dan menumbuhkan lingkungan keluarga, satuan pendidikan, satuan kerja, dan komunitas yang ramah dan bebas kekerasan.

Keempat, Program Gerakan Indonesia Mandiri. Program ini fokus padapeningkatan perilaku yang mendukung tercapainya kemandirian bangsa dalam berbagai sektor kehidupan, peningkatan perilaku yang mendukung tercapainya pertumbuhan kewirausahaan dan ekonomi kreatif, peningkatan peran koperasi dan UMKM terhadap ekonomi nasional,peningkatan apresiasi seni, kreativitas karya budaya dan warisan budaya, peningkatan perilaku yang mendukung tercapainya pemerataan ekonomi dan pengembangan potensi daerah tertinggal, peningkatan perilaku yang mendukung penggunaan produk dan sebesar-besarnya komponen dalam negeri.

Kelima, Program Gerakan Indonesia Bersatu. Program ini fokus pada peningkatan perilaku yang mendukung kehidupan demokrasi Pancasila, peningkatan perilaku toleran dan kerukunan inter dan antar umat beragama, peningkatan perilaku yang mendukung kesadaran nasionalisme, patriotisme, dan kesetiakawanan sosial, peningkatan kebijakan yang mendukung persatuan dan kesatuan bangsa, peningkatan perilaku yang memberikan pengakuan dan perlindungan terhadap kaum minoritas, marjinal, dan berkebutuhan khusus.

Kaitannya dengan revolusi mental dan pemberdayaan masyarakat desa, maka yang perlu kita cari dasar dulu adalah tingkat dan kualifikasi desa secara menyeluruh atau nasional. Berdasarkan mandat Undang-Undang No 6 Tahun 2014 tentang Desa, bahwa pembangunan perlu dilaksanakan secara partisipatif. Pembangunan dilakukan desa, dimana desa melakukan pengelolaan pembangunan, mulai dari perencanaan, penganggaran, pelaksanaan, hingga monitoring dan evaluasi. Disamping itu, selain dapat melakukan pembangunan secara mandiri oleh desa, pembangunan juga dapat melibatkan kerjasama antar desa. Hal ini dilakukan terkait dengan suatu pembangunan yang tidak dapat dilakukan sendiri oleh desa baik dikarenakan oleh keterbatasan dana maupun waktu pelaksanaan.

Tujuan pembangunan desa (desa membangun) adalah meningkatkan kesejahteraan masyarakat desa dan kualitas hidup manusia serta penanggulangan kemiskinan. Cakupan dari kegiatan pembangunan, antara lain: a) Pemenuhan kebutuhan dasar; b) Pembangunan sarana dan prasarana desa; c) Pengembangan potensi ekonomi lokal; d) Pemanfaatan sumberdaya alam dan lingkungan secara berkelanjutan. Dimana prioritas program kegiatan yang dilakukan, yaitu: a) Peningkatan kualitas dan akses terhadap pelayanan dasar; b) Pembangunan dan pemeliharaan infrastruktur dan lingkungan berdasarkan kemampuan teknis dan sumberdaya lokal yang tersedia; c) Pengembangan ekonomi pertanian berskala produktif; d) Pengembangan dan pemanfaatan teknologi tepat guna untuk kemajuan ekonomi; dan e) Peningkatan kualitas ketertiban ketenteraman masyarakat desa berdasarkan kebutuhan, pengelolaan 
pembangunannya dilakukan oleh Pemerintah Desa dan masyarakat desa dengan semangat gotong royong serta memanfaatkan kearifan lokal dan sumberdaya alam desa.

Sedangkan fokus pembangunan dalam konsep membangun desa adalah peningkatan kualitas pelayanan, pembangunan, dan pemberdayaan masyarakat desa melalui pendekatan partisipatif dengan tata ruang Kabupaten atau Kota sebagai acuan. Konsep membangun desa mencakup penyusunan rencana tata ruang kawasan perdesaan secara partisipatif, pengembangan pusat pertumbuhan antar desa secara terpadu, penguatan kapasitas masyarakat, kelembagaan dan kemitraan ekonomi serta pembangunan infrastruktur antar kawasan.

Indeks Desa Membangun mengklasifikasi Desa menjadi lima status yakni Desa sangat tertinggal, Tertinggal, Berkembang, Maju, dan Mandiri. Klasifikasi dalam lima status itu untuk mempertajam penetapan status perkembangan desa sekaligus sebagai rujukan intervensi kebijakan. Status Desa
Tertinggal misalnya dibadi menjadi dua status yakni Desa Sangat Tertinggal dan Desa Tertinggal. Asumsi yang ingin dibangun, afirmasi kebijakan untuk Desa Sangat Tertinggal tentu berbeda dengan Desa Tertinggal.

Desa berkembang terkait dengan situasi dan kondisi dalam status Desa Tertinggal dan Desa Sangat Tertinggal dijelaskan dengan faktor kerentanan. Apabila ada tekanan faktor kerentanan seperti goncangan ekonomi, bencana alam, atau konflik sosial maka dapat memengaruhi status Desa Berkembang turun menjadi Desa Tertinggal. Sementara, apabila Desa Berkembang mempunyai kemampuan dalam mengelola potensi, informasi / nilai, inovasi / prakarsa, dan kewirausahaan akan mendukung gerak kemajuan Desa Berkembang menjadi Desa Maju. Indeks Desa Membangun merupakan komposit dari ketahanan sosial, ekonomi dan ekologi.

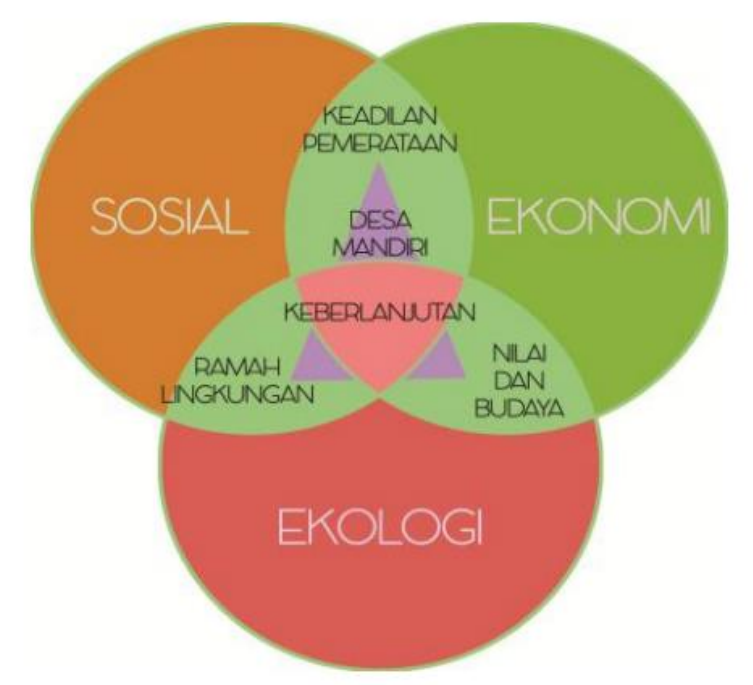

Gambar 1. Indeks Pembangunan Desa oleh Bappenas

Sedangkan perbandingan antara status desa dan indeks desa membangun dijelaskan pada tabel berikut:

\begin{tabular}{|l|l|l|l|}
\hline No & \multicolumn{1}{|c|}{ Status Desa } & \multicolumn{1}{|c|}{ Indeks Desa Membangun } & \multicolumn{1}{c|}{ Indeks Pembangunan } \\
\hline 1 & Sangat Tertinggal & 13.453 Desa $(18,25 \%)$ & - \\
\hline 2 & Tertinggal & 33.592 Desa $(45,57 \%)$ & 19.994 Desa $(26,92 \%)$ \\
\hline 3 & Berkembang & 22.882 Desa $(31,04 \%)$ & 51.127 Desa $(69 \%)$ \\
\hline 4 & Maju & 3.608 Desa $(4,89 \%)$ & - \\
\hline 5 & Mandiri & 174 Desa $(0,24 \%)$ & 3.022 Desa $(4,08 \%)$ \\
\hline
\end{tabular}

Selebihnya dijabarkan dalam diagram berikut ini. 
STATUS DESA BERDASARKAN IDM PER PROVINSI

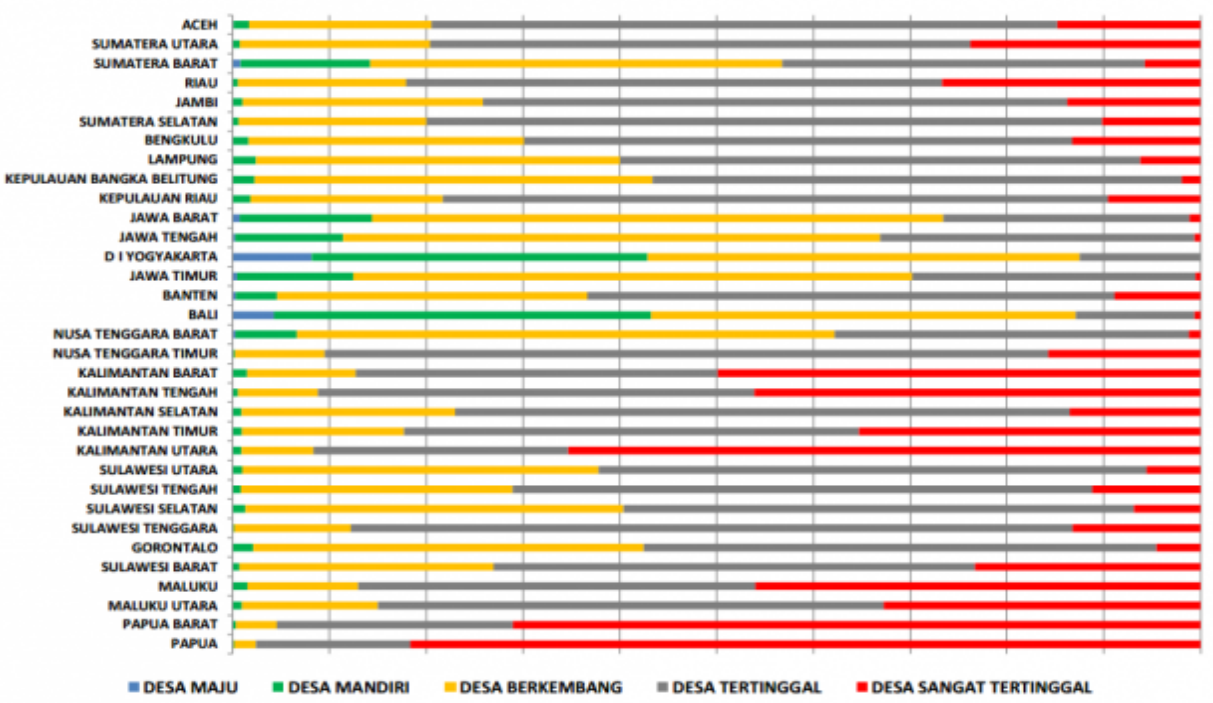

Gambar 2. Diagram Status Desa Berdasarkan IDM Per Provinsi

Secara yuridis, keberaaan desa dan pengaturan tentang desa sudah dituangkan dalam peraturan perundang-undangan. Ini melihat bahwa keberadaan desa merupakan ujung tombak kemajuan suatu negera sehingga perlu regulasi tersendiri untuk desa. Pentingnya UU Desa disampaikan Menteri Dalam Negeri Ga- mawan Fauzi seperti tertuang dalam Keterangan Pemerintah tertanggal 2 April 2012 berikut ini:

"Undang-Undang tentang Desa bertujuan hendak mengangkat Desa pada posisi subjek yang terhormat dalam ketatanegaraan Republik Indonesia. Hal lain adalah bahwa pengaturan Desa akan menentukan format Desa yang tepat sesuai dengan konteks keragaman lokal. Penguatan kemandirian Desa melalui Undang- Undang tentang Desa sebenarnya juga menempatkan Desa se- bagai subjek pemerintahan dan pembangunan yang betul-betul berangkat dari bawah (bottom up)".

Undang-Undang No. 22 Tahun 1999 menegaskan bahwa Desa bukan lagi sebagai wilayah administratif, bahkan tidak lagi menjadi bawahan atau unsur pelaksana daerah, tetapi menjadi daerah yang istimewa dan bersifat mandiri yang berada dalam wilayah kabupaten, sehingga setiap warga Desa berhak berbica- ra atas kepentingan sendiri sesuai kondisi sosial budaya yang hidup di lingkungan masyarakatnya.

Menurut Hanif Nurcholis, di bawah UU No. 5 Tahun 1979, UU No. 22 Tahun 1999, dan UU No.
32 Tahun 2004, status Pe- merintahan Desa adalah lembaga semi formal yang diberi tugas pemerintah atasan untuk mengurus urusan pemerintahan di tingkat Desa. Desa disebut sebagai lembaga semi formal kare- na dibentuk negara melalui undangundang dan mendapatkan dana dari negara. Tetapi Kepala Desa dan perangkatnya bukan oficial government atau civil servant sebagaimana dimaksud UU No. 5 Tahun 2014 tentang Aparatur Sipil Negara.

\section{b. Keberadaan Desa Tanjung Buka}

Desa persiapan Tanjung Raya SP.8, Desa Induk Tanjung Buka SP.8 Kecamatan Tanjung Palas Tengah Kabupaten Bulungan, terdiri dari sembilan RT (Rukun Tetangga) dan dipimpin oleh Kepala Desa persiapan bernama Bapak Suryadi.

Desa persiapan Tanjung Raya SP.8, Desa Tanjung Buka secara geografi terletak di wilayah tropis.

1. Luas dan Batas Wilayah

a. Letak Geografis lokasi

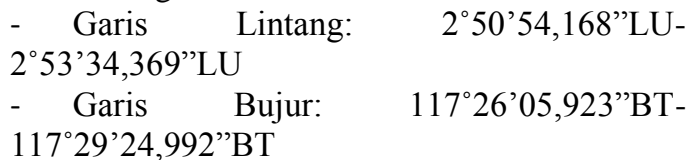

b. Luas Desa: $\pm 1.227,67 \mathrm{Ha}$

c. Perbatasan Wilayah

- $\quad$ Sebelah Utara: UPT. Tanjung Buka SP.7

- Sebelah Barat: Sungai Lebak Pengantin / S.Selimban

- Sebelah Selatan: UPT Selimau II/III (S.Sabanar)

- $\quad$ Sebelah Timur: Kampung Tias

2. Kondisi Geografis 
a. Ketinggian Tanah dari permukaan laut: \pm $12 \mathrm{~m} \mathrm{dpl}$

b. Curah Hujan: $10 \mathrm{~mm} / \mathrm{tahun}$

c. Topografi (Tinggi, Rendah, Pantai): Rendah

d. Suhu Udara Rata-rata: $33,99{ }^{\circ} \mathrm{C}$

3. Orbitas (Jarak dari Pusat Pemerintah Desa)
a. Jarak dari Desa Induk
: $10 \mathrm{KM}$
b. Jarak dari Kecamatan
$: \pm 12 \mathrm{KM}$
c. Jarak dari Kabupaten
$: \pm 12 \mathrm{KM}$
d. Jarak dari Provinsi
$\pm 12 \mathrm{KM}$

Adapun keadan penduduk secara keseluruhan dari desa Tanjung Buka SP. 8 adalah sebagai berikut:

a. Jumlah penduduk, berdasarkan data tahun 2017 jumlah penduduk desa Tanjung Buka SP.8 berdasarkan jenis kelamin laki - laki berjumlah 181 jiwa dan perempuan berjumlah 145 jiwa. Total jumlah penduduk 326 jiwa.

b. Agama, mayoritas penduduk desa Tanjung Buka SP.8 menganut agama islam 322 jiwa dan kristen/prostestan 4 jiwa.

c. Etnis, mayoritas penduduk desa Tanjung Buka SP.8 adalah Jawa, Bugis dan Dayak. d. Mata pencaharian penduduk desa Tanjung Buka SP.8 secara umum adalah bidang pertanian.

e. Pendidikan penduduk desa Tanjung Buka SP.8 secara umum adalah segala tingkatan (SD, SMP, SMA, dan S1).

Rencana pembangunan desa Tanjung Buka SP.8 merupakan suatu upaya untuk membangun desa definitif menjadi desa persiapan Tanjung Raya yang mana bertujuan untuk meningkatkan kesejahteraan masyarakat yang berada diwilayah desa Tanjung Buka khususnya SP.8. Terdapat beberapa kegiatan yang mampu menyejahterakan masyarakat yang berada diwilayah tersebut. Adapun rencana program desa Tanjung Buka SP.8 tahun 2017/2018 yaitu:

1. Meningkatkan perekonomian.

2. Membangun infrastruktur.

3. Menjalankan pemerintahan yang bersih.

4. Menciptkan keharmonisan antara warga.

\section{d. Pelaksanaan Kegiatan Desa Tanjung Buka}

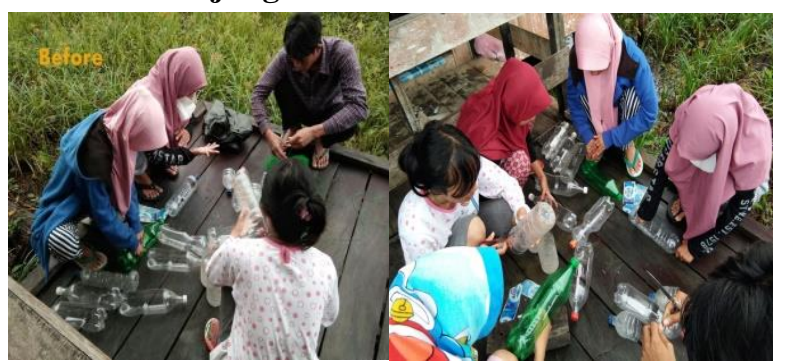

Gambar 3. Sebelum pelaksaan kegiatan yakni pengumpulan sampah yang bisa didaur ulang dan dimanfaatkan

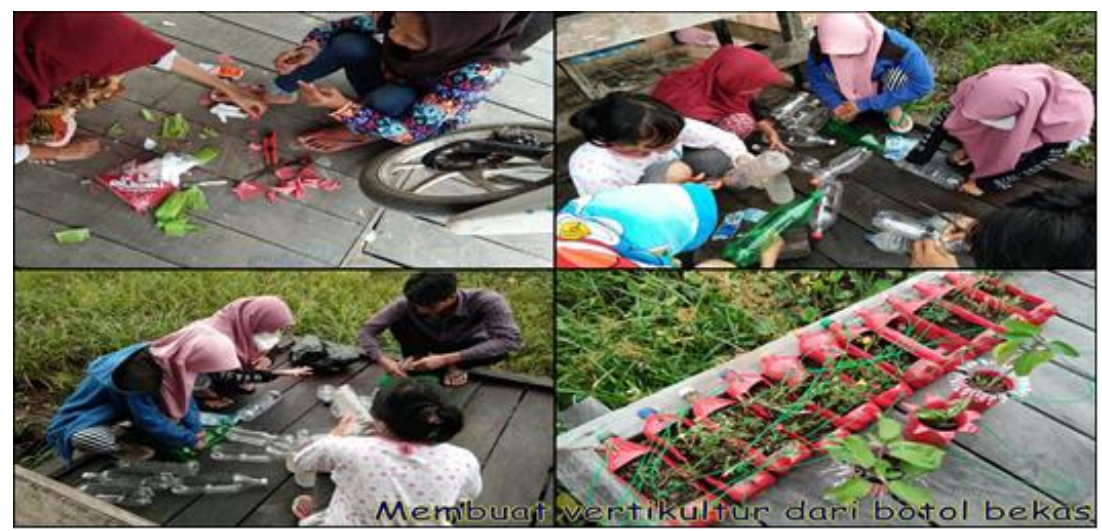

Gambar 4. Setelah dilakukan sosialisasi, maka hasilnya tergampar pada foto di atas 
Diterima: Mei 2018

Disetujui: Junii 2018

Dipublikasikan: Juni 2018

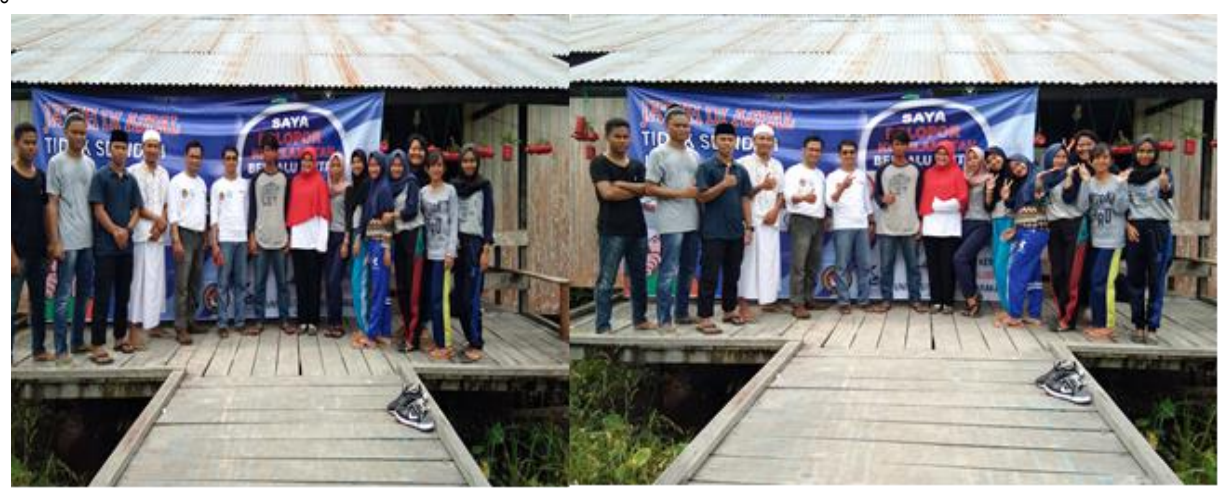

Gambar 5. Penyerahan bantuan spanduk yang bertemakan Revolusi Mental (Indonesia Bersih dan Indonesia Mandiri)

Melalui Revolusi Mental, diharapkan upaya masyarakat desa Tanjung Buka dapat berperan aktif dalam menggali dan memanfaatkan apa yang ada di desa tersebut. Berikut dijelaskan dalam gambar.

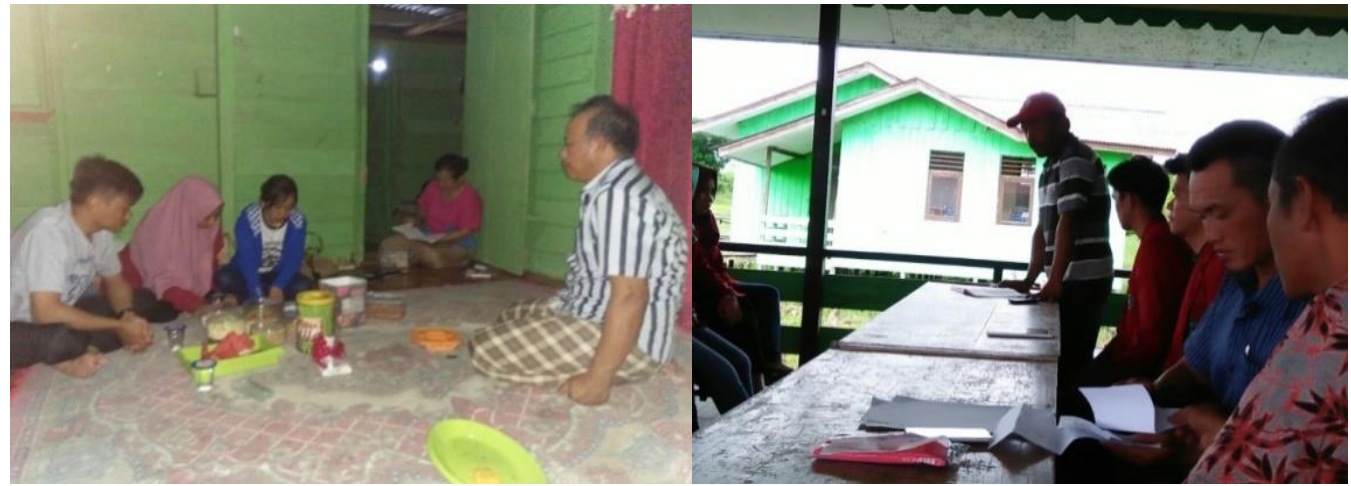

Gambar 6. Pendataan masyarakat yang berpartisipasi dalam usaha kelompok tani atau dikenal dengan koperasi. Diharapkan dapat terbentuk Badan Usaha Milik Desa (BUMDES)

d. Pelaksanaan Kegiatan Desa Gunung Putih

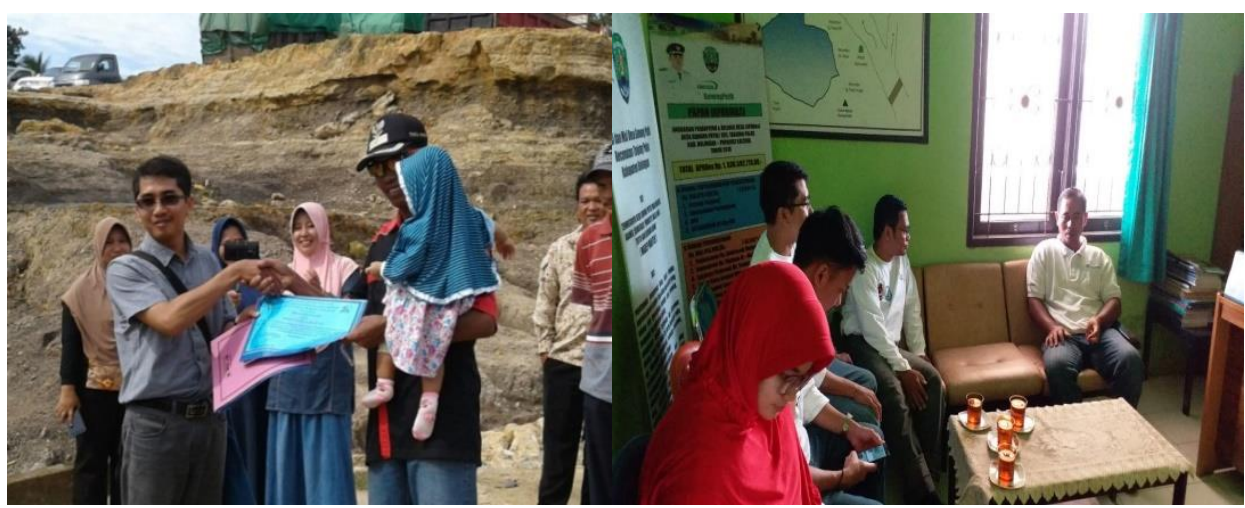

Gambar 7. Kegiatan koordinas rencana pelaksanaan pengabdian kepada masyarakat Desa Gunung Putih Kecamatan Tanjung Palas Kabupaten Bulungan

Kegiatan koordinas rencana pelaksanaan pengabdian kepada masyarakat khususnya Desa Gunung Putih Kecamatan Tanjung Palas Kabupaten Bulungan. Maksud dilakukan koordinasi adalah untuk menyamakan persepti di tingkat jajaran Desa, sehingga diharapkan kegiatan yang akan kami laksanakan dapat terlaksana dengan baik. 


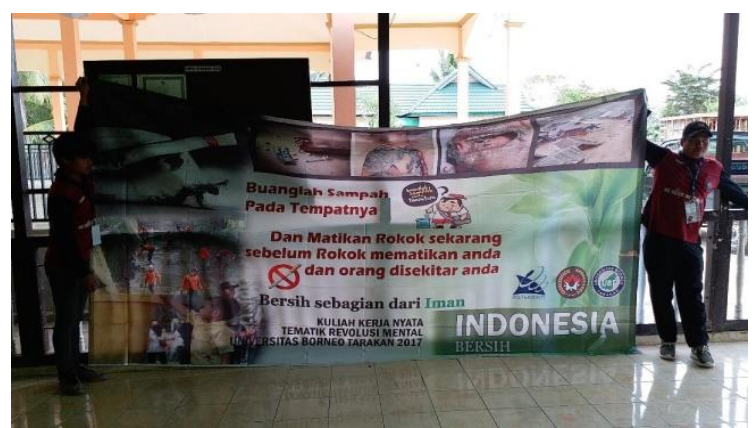

Gambar 8. Pemberian spanduk untuk lingkungan Desa

Pemberian Spanduk sebagais sarana untuk membina persepsi dan merubah mainset masyarakat sehingga dengan melihat spanduk yang cukup besar, maka

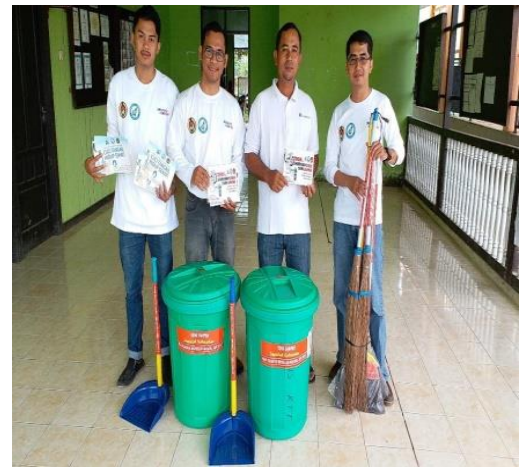

masyarakat sadar akan kebersihan yang ada di lingkungan desa mereka.

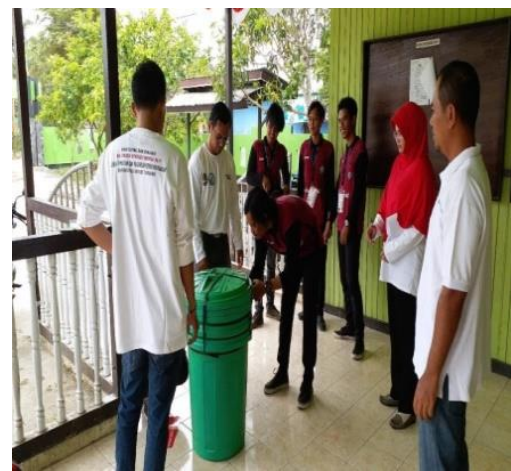

Gambar 9. Pemberian alat kebersihan untuk lingkungan Desa

Selain pemberian spanduk sebagai upaya kami dalam merubah mainset pola masyarakat, kami juga memberi bantuan berupa alat kebersihan seperti Sapu Lidi, Tong Sampah dan juga sapu. Alat-alat tersebut diharapkan dapat membantu mereka dalam kebersihan khususnya dilingkungan Kantor Desa, karena identifikasi awal yang telah kami lakukan ketidak tersediaan sarana kebersihan di Kantor Desa khususnya Tong Sampah. Himbauan tim pelaksana dalam melakukan penyuluhan adalah mengupayakan kepada masyarakat untuk dapat menyediakan bak sampah disetiap rumah mereka, sehingga kebersihan lingkungan di Desa dapat terjaga dengan baik.

Kendala yang terjadi di masyarakat berkaitan dengan sampah adalah, pengolahan akhir. Karena selama ini tidak ada fasilitas yang disediakan oleh Pemerintah Kabupaten Bulungan dalam pengangkutan sampah di desa mereka. Sehingga saran yang kami berikan adalah pengelolaan sampah mandiri dan lebih dikelola masyarakat setempat bisa memanfaatkan limbah baik limbah rumah tangga maupun limbah yang lainnya.

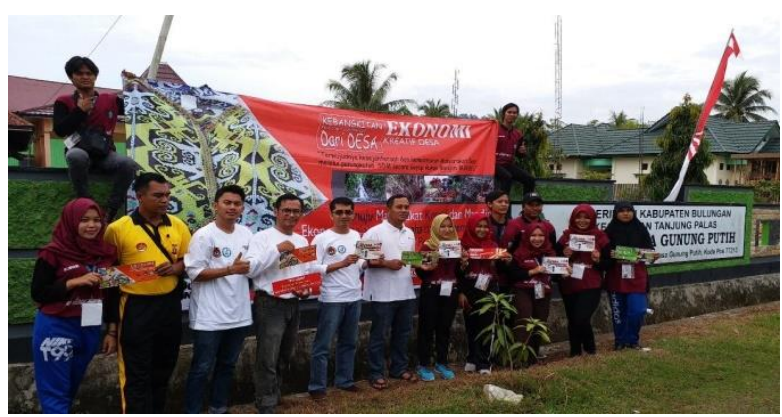

Gambar 10. Kegiatan penyuluhan sekaligus pemberian spanduk menuju Indonesia Mandiri (Desa Gunung Putih Mandiri)

Kemandirian Desa Gunung Putih terlihat dari potensi yang ada di desanya adalah tumbuh subur rumput gajah. Potensi tersebut dimanfaatkan oleh desa sebagai pupuk organic, namun yang menjadi kendala mereka adalah pengemasan dan juga pemasaran. Saran yang kami berikan adalah pewarnaan paking plastik yang cerah sehingga menarik pembeli dan untuk pemasarannya 

pemerintah daerah baik melalui pameran-pameran regional maupun pameran skala nasional.

\section{KESIMPULAN}

Dari hasil pelaksanaan kegiatan dapat ditarik kesimpulan bahwa, wilayah transmigrasi yang ada di Kabupaten Bulungan terdiri dari variasi kemajuan tergantung dari lamanya mereka menetap di lokasi transmigrasi. Untuk Desa Gunung Putih masyarakatnya sudah lama membaur dengan masyarakat local sehingga suasana transmigrasi sudah hampir tidak Nampak dari luar, hal ini dikarenakan akses untuk menuju ke desa tersebut sangat mudah. Sedangkan untuk Desa Tanjung Buka terlihat suasana transmigrasi yang masih baru meskipun mereka menempati lokasi transmigrasi hampir 10 (sepuluh) tahunan. Meskipun 2 (dua) desa tersebut berbeda kemajuannya, tetapi untuk menuju Indonesia Bersih dan Mandiri masih sangat minim, hal ini dikarenakan ketidak pedulian amsyarakat atas lingkungan dan potensi yang dapat mereka manfaatkan untuk kemandirian desanya.

\section{DAFTAR PUSTAKA}

Hanif Nurkholis, "Tantangan dan Prospek Implementasi UU No. 6/2016 tentang Desa," makalah disampaikan dalam Seminar Nasional Administrasi Negara di FISIP Universitas Negeri Padang, 13 November 2014.

Iwan Eka Setiawan, 2016. Materi ToT Pembentukan Gugus Tugas Gerakan Nasional Revolusi Mental, Kementerian Koordinator Bidang Pembangunan Manusia dan Kebudayaan Republik Indonesia, Tanggerang, 14 Februari.

Lala M Kolopaking dkk, 2016. Mekanisme Perencanaan Desa Membangun dan Membangun Desa, Working Paper, Pusat Studi Pembangunan Pertanian Pedesaan LPPM Institute Pertanian Bogor, Vol 1 Nomor 1, Januari.

Muhammad Yasin, dkk, 2015. Anotasi UndangUndang Nomor 6 Tahun 2014 Tentang Desa, Jakarta: Pusat Telaah dan Informasi Regional (PATTIRO).

Yudi Latif, 2014. "Keharusan Revolusi Mental", dalam Jansen Sinamo (ed.), Revolusi Mental, dalam Institusi, Birokrasi dan Korporasi, Jakarta: Institut Darma Mahardika.

http://www.hukumonline.com/berita/baca/lt58747faf 1bd8e/5-program-dalam-inpres-gerakannasional-revolusi-mental, diakses pada tanggal 15 November 2017 pukul 10.20 WITA.

https://sekolahdesa.or.id/indeks-desa-membangundan-pembangunan-desa/ dikases pada tanggal 17 November 2017 pukul 12.10 WITA. 